


\title{
PENGELOLAAN PROGRAM OPEN DEFECATION FREE(ODF) DI PUSKESMAS TEMAYANG KABUPATEN BOJONEGORO TAHUN 2018
}

Farah Shabrina, Hadi Suryono, Mamik

\begin{abstract}
ABSTRAK
Berdasarkan data profil kesehatan Kabupaten Bojonegoro Tahun 2016 dari seluruh desa di Kecamatan Temayang, sebanyak 58,4 \% belum ODF. Penerapan manajemen pada program ODF yang mereka lakukan diketahui terdapat kendalakendala diantaranya adalah keterbatasan tenaga kesehatan lingkungan di puskesmas yang merangkap tugas non kesehatan lingkungan, pelaksanaan program yang dilakukan tidak sesuai dengan perencanaan yang telah disusun, serta dukungan pemerintah desa masih kurang. Tujuan dari penelitian ini adalah untuk mengetahui pengelolaan program Open Defecation Free (ODF) secara manajerial di Puskesmas Temayang Kabupaten Bojonegoro Tahun 2018. Penelitian ini merupakan penelitian survey deskriptif dengan pendekatan cross sectional. Pengumpulan data dilakukan dengan observasi dan wawancara kepada seluruh pelaksana program ODF di Puskesmas Temayang berjumlah 21 responden. Data yang diperoleh dianalisis secara deskriptif.

Hasil penelitian menunjukkan bahwa bahwa penerapan fungsi-fungsi manajemen pada pengelolaan program ODF di wilayah kerja Puskesmas Temayang adalah baik dengan prosentase sebesar 78,6\%. Beberapa komponen yang belum terlaksana dengan maksimal, diantaranya adalah belum adanya pembagian tugas, tidak sesuainya pelaksanaan kegiatan dengan jadwal, kurangnya tenaga pelaksana, belum adanya kebijakan, pemantauan kegiatan dan sumber daya, koreksi kegiatan, dan pendampingan terhadap masyarakat yang terpicu belum berjalan dengan optimal. Adapun saran yang dapat diberikan meliputi menyusun pembagian tugas masing-masing anggota tim kelompok kerja, SOP untuk petugas pelaksana, jadwal kegiatan secara rinci untuk program ODF, menyusun kebijakan berupa pedoman yang dapat digunakan sebagai acuan, melakukan pendampingan kepada masyarakat melalui kerja sama dengan kader dan petugas desa serta meningkatkan koordinasi lintas sektor dengan desa dan kecamatan.

Kata Kunci : Pengelolaan, Open Defecation Free
\end{abstract}

\section{A. Pendahuluan}

Sanitasi menurut WHO adalah suatu upaya mengawasi beberapa faktor lingkungan fisik yang berpengaruh pada manusia terutama terhadap hal-hal yang berpengaruh terhadap perkembangan fisik, kesehatan dan kelangsungan hidup manusia.

$$
\text { Sebagaimana negara }
$$

berkembang lainnya, Indonesia pada saat ini juga menghadapi masalah di bidang sanitasi salah satunya adalah perilaku BABS (Ditjen PP\&PL, 2013). Dalam situs 
resmi STBM Indonesia, sebanyak 59,56 juta jiwa penduduk Indonesia masih melakukan BABS.

Upaya pemerintah dalam meningkatkan derajat kesehatan masyarakat melalui program nasional STBM difokuskan pada pilar pertama yaitu stop BABS karena pilar itulah yang membuka pintu utama menuju sanitasi total dan dapat memutus mata rantai kontaminasi kotoran manusia pada lingkungan. Pemerintah telah menetapkan target dalam RPJMN Tahun 2015-2019, yaitu tercapainya kondisi Bebas dari BABS atau ODF bagi seluruh penduduk.

Menurut Notoatmodjo dalam Herlambang dan Murwani (2012), manajemen kesehatan adalah suatu kegiatan atau suatu seni untuk mengatur petugas kesehatan dan nonpetugas kesehatan guna meningkatkan kesehatan masyarakat melalui program kesehatan.

Berdasarkan data profil kesehatan Kabupaten Bojonegoro Tahun 2016 dari seluruh desa di Kecamatan Temayang, sebanyak $58,4 \%$ belum ODF. Dalam penerapan manajemen pada program ODF yang mereka lakukan diketahui terdapat kendala-kendala diantaranya adalah keterbatasan tenaga kesehatan lingkungan di puskesmas yang merangkap tugas non kesehatan lingkungan, pelaksanaan program yang dilakukan tidak sesuai dengan perencanaan, serta dukungan pemerintah desa yang masih kurang. Tujuan dari penelitian ini adalah untuk mengetahui pengelolaan program Open Defecation Free (ODF) secara manajerial di Puskesmas Temayang Kabupaten Bojonegoro.

\section{B. METODOLOGI PENELITIAN}

Jenis penelitian yang digunakan dalam penelitian ini adalah peneltian survey deskriptif untuk membuat gambaran mengenai pengelolaan program ODF di Puskesmas Temayang Kabupaten Bojonegoro dengan pendekatan cross sectional dimana pengumpulan data dilakukan pada waktu yang bersamaan. (Notoatmodjo, 2010). 
Objek penelitian ini adalah pengelolaan program Open Defecation Free (ODF) di Puskesmas Temayang Kabupaten Bojonegoro. Sedangkan subjek penelitian ini adalah seluruh pengelola dan pelaksana program ODF yang meliputi: kepala Puskesmas Temayang, sanitarian Puskesmas Temayang, camat Temayang, 6 Kepala Desa yang belum ODF, 6 Bidan Desa yang belum ODF dan 6 Kader Desa yang belum ODF.

Observasi dilakukan terhadap penerapan fungsi-fungsi manajemen yang meliputi perencanaan, pengorganisasian, pelaksanaan, dan pengawasan, didukung dengan wawancara terhadap responden. Hasil observasi akan dinyatakan baik jika skor penilaian 31-46 (67,4\% $100 \%)$, cukup jika skor penilaian $15-30(32,6 \%$ - 65,2\%), dan kurang jika skor penilaian < 15 (< $32,6 \%$ ). Analisis data dilakukan secara deskriptif yaitu menggambarkan obyek yang diteliti dengan tabel hasil data yang diperoleh.

\section{HASIL DAN PEMBAHASAN}

Pengelolaan program ODF di Puskesmas Temayang Kabupaten Bojonegoro dilakukan dengan menerapkan fungsi-fungsi manajemen yang meliputi perencanaan (planning), pengorganisasian (organizing), pelaksanaan (actuating), dan pengendalian (controlling). Dengan menerapkan manajemen pada program ODF diharapkan dapat meningkatkan angka masyarakat yang buang air besar di jamban.

\section{Tabel 1.}

TOTAL HASIL PENERAPAN FUNGSI MANAJEMEN PADA PROGRAM ODF DI WILAYAH KERJA PUSKESMAS

TEMAYANG KABUPATEN BOJONEGORO TAHUN 2018

\begin{tabular}{clc}
\hline No. & $\begin{array}{c}\text { Fungsi-Fungsi } \\
\text { Manajemen }\end{array}$ & $\begin{array}{c}\text { Hasil } \\
\mathbf{( \% )}\end{array}$ \\
\hline 1. & Perencanaan & 92,8 \\
2. & Pengorganisasian & 83,3 \\
3. & Pelaksanaan & 69,2 \\
4. & Pengawasan & 69,2 \\
\hline Rata-rata (\%) & $\mathbf{7 8 , 6}$ \\
\hline
\end{tabular}

\section{Perencanaan}

Perencanaan merupakan fungsi dasar dari manajemen suatu program yang akan dilaksanakan dengan merencanakan tujuan, target, 
sasaran, dana, penjadwalan

kegiatan untuk saat ini maupun bulan-bulan selanjutnya dengan melibatkan beberapa orang yang tergabung agar dapat bekerja sama menyamakan tujuan dan kegiatan yang akan dilaksanakan.

Penerapan fungsi perencanaan pada program ODF di Puskesmas Temayang telah terlaksana dengan baik, dengan prosentase sebesar 92,8\%. Namun, terdapat 1 komponen yang belum terlaksana dengan optimal yaitu pembagian tugas dalam jadwal kegiatan. Menurut Muninjaya (1999), menentukan jenis tenaga pelaksana beserta uraian tugasnya merupakan salah satu manfaat fungsi perencanaan. Pembagian tugas ini berfungsi untuk membagi tugas pada setiap kegiatan yang direncanakan agar kegiatan dapat ditangani dan berjalan dengan lancar.

2. Pengorganisasian

Fungsi pengorganisasian merupakan bagian penting yang berfungsi untuk menetapkan, menggolong-golongkan dan mengatur berbagai macam kegiatan, penetapan tugastugas dan wewenang seseorang, dan pendelegasian wewenang dalam mencapai tujuan.

\section{Penerapan}

fungsi pengorganisasian pada program ODF di Puskesmas Temayang telah terlaksana dengan baik yaitu dengan disusunnya kelompok tim kerja. Namun terdapat 1 komponen yang kurang memenuhi yaitu disusunnya job description belum berjalan dengan baik sesuai dengan pembentukan tim kelompok kerja yang telah direncanakan. Berdasarkan observasi yang dilakukan berupa penelusuran dokumen, belum ada uraian tugas yang jelas untuk masing-masing jabatan setelah dibentuk tim kelompok kerja. Menurut Muninjaya (1999), organisasi bermanfaat untuk memadukan (sinkronisasi) organisatoris antar orang-orang di dalam organisasi tersebut melalui kegiatan yang dilakukannya, 
oleh karena itu melalui organisasi tersebut dapat terbentuk suatu interaksi antar anggota agar menjalin kerjasama sehingga dapat mencapai tujuan yang diharapkan.

3. Pelaksanaan

$$
\text { Fungsi pelaksanaan }
$$
merupakan salah satu fungsi manajemen untuk melaksanakan seluruh rencana kerja yang telah disusun dalam perencanaan dan dengan melibatkan anggota-anggota sesuai dengan tugas dan wewenang masing-masing sehingga dapat tercapai tujuan yang diharapkan.

Penerapan fungsi pelaksanaan pada program ODF di Puskesmas Temayang telah terlaksana dengan baik, dengan prosentase sebesar 69,2\%. Namun terdapat beberapa komponen yang belum terlaksana dengan optimal, diantaranya adalah waktu yang telah direncanakan dalam jadwal kegiatan belum dapat dilaksanakan dengan tepat karena sering terjadi tumpang tindih dengan kegiatan yang lain.

Pembagian tugas tidak terlaksana karena belum tercantum dalam jadwal kegiatan. Sehingga kegiatan yang dilaksanakan oleh anggota seperti penyuluhan tidak mengacu pada jadwal kegiatan yang telah disusun.

Keterbatasan tenaga sanitasi yang dibantu dengan perawat dan bidan desa belum sepenuhnya berjalan dengan maksimal karena masingmasing tenaga memiliki tanggung jawab lain pada bidang mereka.

Kebijakan dalam pelaksanaan kegiatan program ODF telah disusun namun belum diterapkan dengan baik di puskesmas. Sedangkan dari pihak desa sendiri tidak membuat kebijakan untuk program ODF. Kebijakan yang bertujuan untuk mengatasi masalah agar dapat tercapai tujuan yang diharapkan harus diterapkan dalam pelaksanaan kegiatan.

4. Pengawasan 
Melalui fungsi pengawasan, hasil dari pelaksanaan kegiatan dievaluasi dan dibandingkan dengan rencana, target, dan tujuan yang telah disusun, jika terjadi penyimpangan dapat dilakukan perubahan pada perencanaan dan diatur kembali untuk melakukan perbaikan terhadap penyimpangan yang terjadi agar dapat tercapai tujuan yang diharapkan.

\section{Penerapan}

fungsi pengawasan pada program ODF di Puskesmas Temayang telah terlaksana dengan baik, dengan prosentase sebesar 69,2\%. Namun terdapat beberapa komponen yang belum terlaksana dengan optimal, diantaranya adalah pemantauan terhadap kegiatan dan sumber daya sangat penting untuk memastikan bahwa kegiatan dapat berjalan dengan baik sesuai dengan rencana. Menurut Muninjaya (1999), fungsi pengawasan bermanfaat untuk mengetahui adanya penyimpangan pada pengetahuan dan pengertian staf dalam melaksanakan tugas- tugasnya, selain itu juga untuk mengetahui apakah waktu dan sumber daya lainnya telah mencukupi kebutuhan dan telah digunakan secara benar.

Koreksi terhadap kegiatan yang tidak sesuai pelaksanaanya belum dilakukan karena kurangnya waktu. Dalam Permenkes No. 44 Tahun 2016 tentang Pedoman Manajemen Puskesmas, dalam pengawasan dan pengendalian dilakukan koreksi pelaksanaan kegiatan untuk pengembangan di masa mendatang.

Pendampingan terhadap masyarakat yang telah terpicu belum terlaksana dengan baik. Dalam Permenkes No. 3 Tahun 2014, untuk mencapai kondisi sanitasi total dilakukan pendampingan pasca pemicuan yang dapat dilakukan oleh tenaga kesehatan, kader relawan, maupun masyarakat. Pendampingan pasca pemicuan sangat penting untuk mengawasi dan memberikan motivasi kepada masyarakat yang telah terpicu hingga mereka benar-benar 
menerapkan perilaku stop babs dan membangun jamban yang sehat

\section{KESIMPULAN}

Berdasarkan hasil penelitian yang telah dilakukan mengenai pengelolaan program ODF di Puskesmas Temayang, dapat disimpulkan bahwa penerapan fungsi-fungsi manajemen pada pengelolaan program ODF di wilayah kerja Puskesmas Temayang adalah baik dengan prosentase sebesar 78,6\%. Adapun perincian tahapan sebagai berikut :

1. Fungsi perencanaan telah diterapkan dengan baik pada program ODF yang meliputi rencana program, penjadwalan, adanya fasilitator, dan rencana dana dengan prosentase sebesar $92,8 \%$.

2. Fungsi pengorganisasian telah diterapkan dengan baik pada program ODF yang meliputi dibentuknya kelompok kerja dan penyusunan uraian tugas (job description) serta wewenang dengan prosentase sebesar $83,3 \%$.
3. Fungsi pelaksanaan telah diterapkan dengan baik pada program ODF dengan prosentase sebesar $69,2 \%$.

4. Fungsi pengawasan telah diterapkan cukup baik pada program ODF dengan prosentase sebesar $69,2 \%$.

\section{E. SARAN}

1. Bagi Puskesmas

a. Menyusun jadwal kegiatan secara rinci untuk program ODF

b. Menyusun uraian tugas (job description) masing-masing anggota tim kelompok kerja program ODF secara jelas sesuai dengan kompetensi yang dimiliki

c. Menyusun SOP untuk petugas pelaksana

d. Memaksimalkan fasilitas untuk tim pemicu berupa surat tugas, surat pemberitahuan dan dukungan pemicuan kepada kepala desa, dusun, RT, dan RW, serta kebutuhan pemicuan (kendaraan dan media) 
e. Menjamin kualitas fasilitator sudah terampil untuk melakukan pemicuan

f. Menyusun kebijakan berupa pedoman yang dapat digunakan sebagai acuan dalam penyelesaian masalah bagi petugas

g. Meningkatkan koordinasi lintas sektor dengan desa dan kecamatan

2. Bagi Pemerintah Desa Temayang

a. Meningkatkan koordinasi dengan puskesmas dan kader yang telah ditunjuk

b. Melakukan pendampingan kepada masyarakat yang telah terpicu

c. Melakukan pendampingan dan pendekatan kepada masyarakat yang telah menerima bantuan jamban

3. Bagi Dinas Kesehatan Kabupaten Bojonegoro

a. Memberikan keterampilan kepada petugas pemicu dengan refreshing pelatihan fasilitator pemicuan

b. Standarisasi untuk petugas pemicu sesuai dengan kompetensi c. Menganalisa kembali petugas pemicu yang ada

\section{DAFTAR PUSTAKA}

Ditjen PP \& PL, Kemenkes RI, (2013). Road Map Percepatan Program STBM Tahun 2013-2015. Jakarta.

Herlambang, Susatyo, dan Murwani, Arita, 2012. Cara Mudah Memahami Manajemen Kesehatan dan Rumah Sakit. Yogyakarta, Gosyen Publishing : 38-39.

Muninjaya, Dr. A.A. Gde, 1999. Manajemen Kesehatan. Jakarta : Penerbit Buku Kedokteran.

Notoatmodjo, Prof. Dr. Soekidjo, 2010. Metodologi Penelitian Kesehatan. Jakarta : Penerbit Rineka Cipta.

Peraturan Menteri Kesehatan Republik Indonesia Nomor 3 Tahun 2014 tentang Sanitasi Total Berbasis Masyarakat.

Peraturan Menteri Kesehatan Nomor 44 Tahun 2016 tentang Pedoman Manajemen Puskesmas. 